\title{
ENTREPRENEURIAL NETWORKING IN SUPPLY CHAIN RELATIONSHIPS IN THE AUTOMOTIVE COMPONENT INDUSTRY
}

\author{
RC O'Neill: University of KwaZulu Natal \\ MJ Naude: University of KwaZulu Natal
}

\section{SYNOPSIS}

Purpose: The point of departure in this article is that the principles that underpin entrepreneurial networking also apply to the establishment of supply chain relationships. The theoretical base for the need for entrepreneurial networking can be found in Kirzner's theory of entrepreneurship that argued that entrepreneurs identify and act upon profit opportunities that exist in disequilibrium in order to equilibrate the economy.

Problem Investigated: This article explores the possibility of implementing entrepreneurial networking in supply chain relationships in the automotive component industry.

Methodology: Kirzner's theory is used as a theoretical base to support the case for the development of supply chain relationships. The literature with regard to supply chain management and its relevance to entrepreneurial networking is first dealt with. The case for implementing entrepreneurial networking to strengthen supply chain relationships in the automotive component industry in South Africa is then presented.

Findings: The findings of this article indicate that the principles underlying entrepreneurial networking could be applied to supply chain relationships in the automotive component industry in South Africa. The argument is mainly based on the sustainability and profitability potential of entrepreneurial networking and the similarities that exist between entrepreneurial networking and supply chain management relationships.

Originality: This research is original as it explores the possibility that the principles that underpin entrepreneurial networking also apply to the establishment of supply chain relationships in the automotive component industry. Furthermore, there is a need for published research in South Africa on supply chain management, particularly relationships within the supply chain.

Conclusion: Based on the sustainability and profitability potential of entrepreneurial networking and the similarities that exist between entrepreneurial networking and supply chain relationships, the principles underlying entrepreneurial networking can be applied to supply chain relationships in the automotive component industry in South Africa. The unique challenges facing this industry in the current global market further strengthen the case for the implementation of entrepreneurial networking.

Key Words: Kirzner's Theory of Entrepreneurship; Networks; Entrepreneurial Networks; Supply Chain Relationships; Challenges of Supply Chain Relationships; Customer Value; Sustainable Competitive Advantage.

\section{INTRODUCTION}

Based on Kirzner's theory of entrepreneurship (Kirzner,1973:14) that argues that entrepreneurs are economic agents that identify and act upon profit opportunities that exist in the market, the point of departure of this article is that: (a) entrepreneurial networking could assist entrepreneurs to identify opportunities in the market more timeously and enable them to take advantage of these opportunities faster than entrepreneurs that lack effective entrepreneurial networks and (b) Kirzner's theory can also be applied to the establishment of supply chain relationships. The application of Kirzner's theory to supply chain relationships is based on the argument that the establishment of entrepreneurial networks and supply chain relationships have the same objective of identifying opportunities in the market. 
This article explores the possibility of implementing entrepreneurial networking in supply chain relationships in the automotive component industry.

In this article, the literature referred to deals with supply chain management and relationships within the supply chain. The literature review will then present an overview of entrepreneurial networking which will be applied to supply chain management. Thereafter, the argument to incorporate entrepreneurial networking into supply chain relationships in the automotive component industry will be presented. The summary, recommendations, limitations and suggestions for further research will then be dealt with.

\section{THEORETICAL BACKGROUND}

The Council of Supply Chain Professionals defines supply chain management as: "managing supply and demand, sourcing raw materials and parts, manufacturing and assembly, warehousing and inventory tracking, order entry and order management, distribution across all channels, and delivery to the customer" (Johnsson, 2005:7).

As indicated in Naude (2009:7), supply chain management is the management of processes involved in sourcing materials, transforming them into components, parts or final products and delivering a product or service. The chain begins with the basic suppliers of raw materials and extends all the way to the final customers. The facilities involved in an assembly-type supply chain such as that of automotive component manufacturers include warehouses, factories, processing centres, distribution centres, retail outlets and offices. Processes include forecasting, planning, purchasing, inventory management, information management, quality assurance, scheduling production, distribution, delivery, disposal and customer service (Heizer \& Render 2008:434; Stevenson 2005:692).

Slone, Mentzer and Dittmann (2007:117) observe that supply chain management is a complex set of activities that permeates many business functions and processes, reaches beyond the business, is driven by fast-changing technologies, and presents many challenges and opportunities that cannot be managed in isolation.

According to Burt, Petcavage and Pinkerton (2010:15), the supply chain stretches from the final customer back to mother earth. The authors view the chain as one unit as opposed to fragmented units, each performing its own task. As can be seen from figure 1, there are five kinds of movement flow in the supply chain: the physical movement of materials, usually in the direction of the end of the chain (which is the focus point of the supply chain); the exchange of information; the fund (money) flow; the relationship flow; and the flow back to mother earth, which would include the recycling, remanufacturing and disposal of products (Stevenson 2005:492; Burt et al 2010:15). 
Figure 1: The supply chain

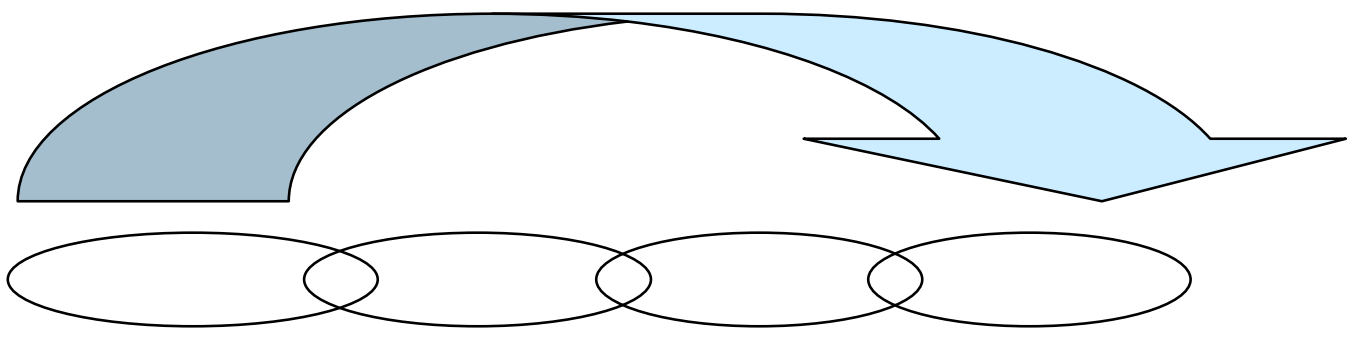
Mother
Extractors
Miners
Harvesters
Converters
and
Suppliers
Original
Earth
Equipment
Manufacturer

(OEM)

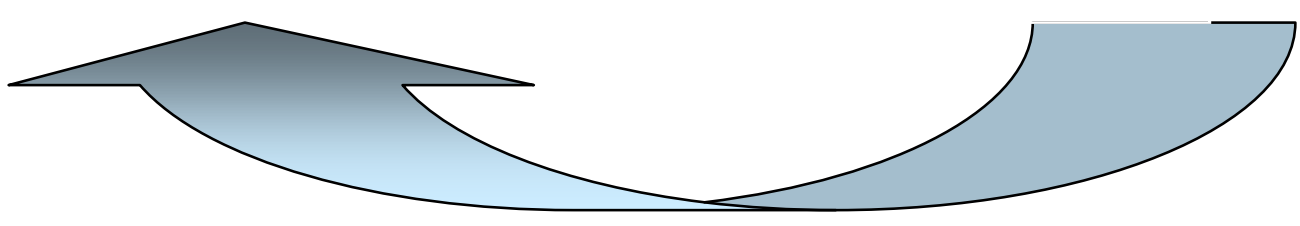

MATERIALS \& SERVICES

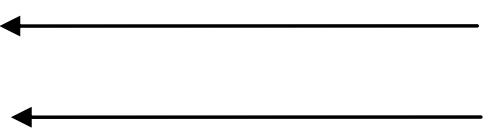

INFORMATION

FUNDS

RELATIONSHIPS

Source: Burt et al (2010:15)

Christopher (2005:5) defines supply chain management as follows: "the management of upstream and downstream relationships with suppliers and customers to deliver superior customer value at less cost to the supply chain as a whole". The author is of the opinion that the main focus of supply chain is on supplier and customer relationships in order for all the parties in the chain to achieve a more profitable outcome.

It can be concluded that supply chain management as a philosophy and concept developed as businesses realised that they need their suppliers to decrease costs and improve efficiency. In turn, their customers also need their cooperation as suppliers to decrease costs and improve efficiency. Thus, supply chain members recognised that by coordinating and managing the supply chain as one process, they could be more efficient together than separately (Hugo, Badenhorst-Weiss \& van Biljon, 2004:10). The word "coordinating" implies a certain relationship between people or groups of people.

\section{Relationships in the Supply Chain}

The supply chain network consists of all businesses involved in a specific supply chain and includes final customers, retailers, wholesalers, first, second, third and even fourth tier suppliers (Hugo, BadenhorstWeiss \& Van Biljon, 2006:104).

As indicated in Beth, Burt, Copacino, Gopal, Lee, Lynch and Morris (2006:65) leading academics in the field of supply chain management have already identified people and relationships as major themes. These authors are of the opinion that the opportunities and challenges of globalisation and pressure for 
speed and cost containment are requiring businesses to establish partnership/alliance relationships with their suppliers.

Traditionally, the majority of businesses were of the opinion that the way in which they managed suppliers was insignificant in their overall performance. Buyers played off suppliers against each other and frequently replaced them. This adversarial model was not ideal. The mindsets about the approaches to be used when dealing with suppliers needed to be developed and to move from purely an adversarial approach to a more collaborative one. As international competitors have proven, joining forces with suppliers can lead to competitive market benefits (Handfield, Monczka, Guinipero \& Patterson 2009:753).

Stevenson (2005:718) confirms that maintaining good relationships with suppliers is increasingly being identified as a critical factor in sustaining a competitive advantage. Currently, many businesses view their suppliers as partners - in other words, they prefer a stable relationship with comparatively few suppliers who can make available high-quality supplies, sustain delivery schedules and remain flexible relative to changes in specifications and delivery schedules.

Liker and Choi (2006:23) acknowledge that businesses are largely relying on their suppliers to reduce costs, enhance quality and develop innovations faster than their competitors' suppliers can. One way of achieving this is to build networks of suppliers that learn, improve and grow.

Burt et al (2010:65) note that buyer-supplier relationships have evolved from being transactional to collaborative to alliance based. For example, the automotive assemblers in South Africa hold a strong position in the automotive industry and because of this, previously, this strength led to adversarial relationships with their suppliers. However, as a result of the lifting of protection, relationships both up and down the supply chain have had to change, and are evolving into partnerships (Williams 2004:1; Naude 2009:74).

\section{Types of buyer-supplier relationships}

Burt et al (2010:66) identify three principal classes of relationships, namely transactional, collaborative and alliance based.

\section{Transactional relationships}

Lysons and Gillingham (2003:378) define a transactional relationship as follows: "A straightforward relationship between buyer and seller whereby the two parties do not get closely involved with each other, but simply exchange goods or services for payment."

Burt et al (2010:66) confirm this by describing this kind of relationship as neither "good nor bad" - it is merely an arm's-length relationship in which neither party is particularly concerned with the other's interests.

\section{Collaborative relationships}

Monczka, Handfield, Guinipero and Waters (2010:103) report that most buyers and sellers recognise a need for co-operation with suppliers, in order to achieve cost, quality, delivery, and time improvements. During the 1980s and 1990s, progressive buyers eliminated poor or marginal suppliers from their supplier database. Today, the goal of many of these buyers is to build collaborative relationships or alliances with current suppliers. The authors define collaboration as follows: "Collaboration is defined as the process by which two or more parties adopt a high level of cooperation to maintain a trading relationship over time."

Burt et al (2010:68) hold that the basic difference between transactional and collaborative relationships is recognition of interdependency of and necessity for cooperation. Recognition of interdependency of and the need for cooperation results in many benefits for both parties such as building trust, communicating, planning and promoting interdependency, which may result in achieving a competitive advantage. Collaborative relationships look out for their "friends" and not their opportunistic customers. Both customers and suppliers see one another in terms of long-term relationships and respect and would probably support one another in difficult times. However, the authors observe that the main weakness of 
such relationships is the amount of human resources and time and energy needed to build and manage these types of relationships.

\section{Alliance relationships}

Burt et al (2010:68) acknowledge that the main distinction between collaborative relationships and alliance relationships is the existence of institutional trust. The authors $(2010: 83)$ observe that trust in alliance relationships is not at all "blind trust" but rather a "prudent trust", which is carefully designed, planned and mutually agreed upon. When alliance relationships are first formed, this trust is usually established interpersonally between the alliance champions and the executives who create this unit. Subsequently, building strong alliance relationships requires hard work and commitment by both parties.

The discussion thus far in this section indicates that relationships in the supply chain are vital. Quesada, Syamil and Doll (2006:30) acknowledge that in industries such as the automotive industry, where value added by suppliers contributes significantly to the final product, the competitiveness of original equipment manufacturers depends upon supplier performance in terms of cost, quality and on-time delivery. It is for this reason that businesses require their suppliers to deliver products in "the right quality, the right quantity, at the right time, at the right place, from the right source at the right price." Consequently, "supply, sourcing and purchasing professionals in companies nationwide believe strongly that more and stronger supplier partnerships are critical to achieving competitive corporate performance" (Wisner, Keong \& Tan, 2005:62). In the light of this, companies are realising the importance of developing "winwin" long-term relationships with suppliers.

\section{Entrepreneurial Networks}

Premaratne (2002:2) defined networks as personal relationships between an entrepreneur and his/hers external actors. This definition is very similar to supply chain relationships. A network is a structure where a number of nodes (entities) are related to each other by specific threads (links). Both threads and nodes are loaded with regard to resources, knowledge and understanding as a result of complex interactions, adaptions and investments within and among firms over time (O'Neill, Soni, Coldwell \& Edmonds, 2007:2). Networking can be seen as a social construction that exists only as a result of the individual's understanding and use of the network (Goudis \& Skuras, 2000:14). Networks refer to a group of firms or people "joining hands" in order to use their combined talents and resources for mutual benefit to achieve superior results that would not have been possible if they acted individually (Dean, Holmes \& Smith, 1997:226). Networks have the potential to facilitate collective action for mutual benefit (Taylor, Jones \& Boles, 2004:226). This potential of networks to facilitate collective action for mutual benefit is similar to the importance of developing "win-win" long-term relationships with suppliers emphasised by Wisner, Keong and Tang ( 2005:62) as explained in the previous paragraph. Because of this potential benefit, networking is usually established for a specific reason or in order to achieve a specific objective.

An entrepreneurial network can be regarded as a series of reciprocal relationships that have the potential to generate customer value and build sustainable competitive advantage for the entrepreneur (O'Neill et al, 2007:2). Competitive advantage in this context can be seen as an advantage gained over competitors that enables the business to offer greater value to customers at lower prices by providing more benefits that justify higher prices (Kotler, Armstrong, Saunders \& Wong, 2002:820-821).

Entrepreneurial networks can help entrepreneurs to achieve their goals and may provide special assistance to entrepreneurs in small and medium-sized enterprises (SMEs) in particular as they usually have limited resources relative to larger businesses (Premaratne, 2002:1). In a business context entrepreneurial networks can be viewed as social businesses that potentially offer different types of resources to start, improve or sustain entrepreneurial projects. The goal of entrepreneurial networks is usually to combine a broad selection of talents, professionals and resources in order to complement each others' endeavours. Implicit in this goal of entrepreneurial networks is the notion that entrepreneurial networking takes place for a reason (O'Neill et al, 2007:2). Burt (1998:205) argued that a well structured network will obtain higher rates of return for the entrepreneur than badly structured networks. The "structural hole is an opportunity to facilitate the flow of information between people and control the form of projects that connect people from opposite sides of the hole" (Burt, 1998:5). The structural hole is also based on the existence of disequilibrium between opposite sides of the hole and therefore shows a strong 
resemblance to Kirzner's theory of entrepreneurship that argued that entrepreneurs identify and act upon profit opportunities that exist in disequilibrium and attempt to equilibrate these opportunities (Kirzner, 1973:73,127). Kirzner's theory that entrepreneurs endeavour to create equilibrium through the identification of and acting upon opportunities that result from disequilibrium in order to create equilibrium in the market is contrary to Schumpeter's theory that entrepreneurs create disequilibrium in order to rearrange the factors of production (Kirzner, 1973: 72-73). For the purposes of this article Burt's structural hole argument as well as Kirzner's theory that entrepreneurs attempt to equilibrate the market will be used to emphasise the need for entrepreneurial networking, as appropriate networks could assist the entrepreneur not only to bridge structural holes but also to create equilibrium in the market.

In both instances the structural holes as well as the identified disequilibrium in the economy present opportunities to the entrepreneur. Networking has the potential to help entrepreneurs to fill these structural holes. Tsai and Ghosal (1998:473) found that the presence of structural holes is positively associated with the extent of resource exchange with other parties which in turn is positively associated with the entrepreneur's innovative ability.

Networks that are rich in the entrepreneurial opportunities offered by structural holes could be regarded as entrepreneurial networks because they present the opportunity for entrepreneurs who are skilled in building interpersonal bridges to span structural holes. In this regard Aldrich (1999:87) emphasised that successful entrepreneurs are not necessarily those who create structural holes but rather those who know how to span the structural holes they find. Healthy supply chain relationships that have the potential to improve the supply chain could serve a similar function to bridging structural holes and equilibrate the market where disequilibrium exists.

A variant of the structural hole argument attributes advantage to the occupation of a bridging position within a network. In this regard McEvily and Zaheer (1999:1152) surveyed 227 job shop manufacturers in Midwest USA and found that lower density networks were associated with greater acquisition and deployment of capabilities necessary for competitiveness in the metalworking segment of the automotive industry. The benefits of the structural hole argument were also supported by the research finding of Baum, Calabrese and Silverman (2000:287) in Canada during the six year period (1991-1996) when comparing 142 start-up biotechnology firms with 471 firms founded prior to 1991 . The research showed the alliance partner heterogeneity had a positive effect on subsequent financial performance and innovative capability. Singh, Hills and Lumpkin (1999:7) surveyed 256 consulting entrepreneurs in the information technology industry and found that in the early stage of the entrepreneurial process, entrepreneurs appear to benefit from diverse information flows. This could most probably be attributed to the diverse needs during the start-up process. Davidsson and Honig (2003:324) conducted a study among nascent entrepreneurs $(n=380)$ and a control group $(n=608)$ in Sweden and followed the development process for 18 months. The study found that being a member of a business network had a statistically significant positive effect on the business in general. Human and Provan (1997:368) in a comparative qualitative study of two networks of small and medium sized manufacturing enterprises in the USA's wood product industry found that network exchanges appeared to add more value with regard to learning about your own organisational capabilities than about market exchanges. It further enhanced knowledge with regard to awareness of who their real competitors were (Human \& Provan, 1997:397).

The research of Hoang and Antocic (2003:165) with regard to previous publications on entrepreneurship, sociology and the role of networks in the entrepreneurial context suggested that research seeking to explain entrepreneurial success is limited by how we measure the networks that help to promote those measures. Mapping networks of general information flows may be too far removed from resource flows and more closely linked to an outcome such as business performance (Hoang \& Antocic, 2003:177). Network data derived from detailed lists of relevant business resources may have more predictive source reliability. The uniqueness of the industry researched should, however, be borne in mind and generalising of findings done with caution (Human \& Provan, 1997:393). Network research can assist practitioners to meet organisational objectives and help proactively to change networks to improve the performance and effectiveness of their organisations (Nobria \& Eccles, 1992:15; Mitchell, Busenitz, Bird, Gaglio, McMullen, Morse \& Smith, 2007:3-4; Thompson, Gamble \& Strickland (2006:195). 
By implication the factors that influence entrepreneurial networks involve the identification of disequilibrium or structural holes (see Burt and Kirzner in previous section):

- $\quad$ the identification of potential network prospects that can help equilibrating the disequilibrium or fill the structural holes;

- the choice of a realistic and limited number of networking prospects given time and human resource restrictions;

- $\quad$ the establishment and maintenance of the selected relationships; and

- $\quad$ reciprocal and mutual benefits to members of the entrepreneurial networking relationship during the period of its existence (O'Neill, 2009: 469).

The measurement of entrepreneurial networks will therefore have to pay ample attention to:

- $\quad$ the reason for the establishment of the network (Edmonds,2005:63);

- $\quad$ the reciprocal nature of the network (O'Neill, 2009:469); and

- the nature of the structure of the network, for example, network size ( depth and width), extent of the network activity (such as frequency of contacts), network diversity and success/failure of the networking with regard to achieving its preconceived goals (Edmonds, 2005:63).

The factors that influence entrepreneurial networks as well as the measurement thereof may be applied to supply chain relationships as well. The case for linking entrepreneurial networking and supply chain relationships will be presented in the next section.

\section{Supply Chain Relationships and Entrepreneurial Networking}

This section of the article deals with the principles relating to supply chain relationships in the automotive industry and entrepreneurial networking.

\section{The need for supply chain relationships}

The significance of the apparent vast and complex supplier base faced by original equipment manufacturers in the automotive industry is that they need to establish strong supply chain relationships with their suppliers in order to remain profitable and competitive. As it would be unrealistic and a waste of time to try to establish strong relationships with many suppliers, original equipment manufacturers need to identify their core suppliers and concentrate on establishing and nurturing strong supply chain relationships with them (Candler 1998:6; Humphrey \& Memedovic, 2003:21). A further example, cited, in lyer, Seshadri and Vasher, (2009:88) is that at Toyota choosing a supplier is a long drawn-out process that involves verifying whether the supplier will fit the supply network. Toyota's goal is to minimise the number of suppliers and create long-term relationships by nurturing existing suppliers.

The principle that original equipment manufacturers should concentrate their supply chain relationships with core suppliers is in line with the requirements of effective entrepreneurial networking to concentrate only on a few networking partners or prospects as well as to network for a reason (Edmonds, 2005:63).

\section{Challenges of supply chain relationships}

Power relationships: Suppliers complain that their "collaborative" supply chain management relationships with original equipment manufacturers are almost exclusively one way and not collaborative at all as the original equipment manufacturers have the power because of their ability to select from a range of competitive suppliers (Belzowski, Flynn, Edwards, Ban and Martin, 2004:18). The implication of this accusation is that due to the luxury of choice and size, an uneven power relationship that favours original equipment manufacturers exists. The ideal of a collaborative relationship as propagated in entrepreneurial network literature appears to be unattainable under such circumstances. The challenge to original equipment manufacturers' suppliers is to differentiate their product offering - for example through innovations that improve processes or decrease costs - so that original equipment manufacturers continue to source and ultimately establish collaborative relationships with them. The nature of such collaborative relationships would be similar to entrepreneurial networks as far as collaboration is concerned. 
Competition: The impact of global competition has forced suppliers at all levels of the supply chain to improve their services to customers (Simchi-Levi, Kaminsky \& Simchi-Levi, 2003:1). As indicated in Monczka et al (2010:170) the three primary criteria for assessing suppliers are listed as price, quality and delivery.

Global economic crisis: As indicated in Naude and O'Neill (2010:8), the global economic crisis has negatively affected the automotive component industry in South Africa. The authors acknowledge that there has been a definite decrease in demand due to the global economic crisis. This decrease was quantified by a $30-40 \%$ drop and in certain companies, a decrease by as much as $50 \%$. This was attributed largely to the difficulty for consumers in attaining credit which has resulted in decreases in automotive purchases and, subsequently, less demand for automotive components. Within their study, several implications for the decreases in demand were also established. These were: reduced profits, retrenchments and closure of companies.

This decrease in demand impacted negatively on local and export sales throughout the automotive industry and resulted in excessive slow-moving inventory. This inventory was slow-moving because the production of motor cars had declined significantly and until demand and production for motor cars improves, this excess will remain (Naude 2009:220).

Considering the limited extent of time and available manpower, the need for cost control and the quest for optimum efficiency, supply chain managers are facing the daunting task of identifying the most appropriate suppliers on the one hand and their most important customers on the other hand (Monczka et al 2010:170). The authors indicate that assessing and choosing the most appropriate suppliers and customers will depend on the following:

- $\quad$ the impact on turnover;

- $\quad$ the impact on profit;

- $\quad$ the potential to reduce cost;

- management of risk;

- $\quad$ the availability of alternative suppliers;

- $\quad$ the availability of alternative customers;

- $\quad$ the potential impact on maintaining production output should suppliers be changed; and

- $\quad$ the impact on the sustainability of the business should a key customer be lost or replaced (Monczka et al 2010:171).

The above-mentioned criteria that are suggested to select the most appropriate suppliers and customers in the supply chain are in line with the principles of bridging the structural hole as well as equilibrating the market. These criteria emphasise the need to establish entrepreneurial networks. The objective of both supply chain relationships and entrepreneurial networking is to optimise the performance of the firm. In order to achieve this optimisation strong supply chain relationships and/or strong entrepreneurial networks are needed to facilitate the optimisation process.

Within the context of the challenges that face the establishment of supply chain relationships, Liker and Choi (2006:23) suggest that American firms, as in the case of their Japanese rivals, should build supplier keiretsu, in other words, "networks of vendors that learn, improve, and prosper in sync with their parent companies."

The key requirements for effective supply chain relationships are: collaboration, integration and trust (Hauser, Davis \& Graham, 2003:1). Trust can be regarded as the foundation for business and suppliers to enter into long-term relationships that allow them to share and integrate data and collaborate in the development of long-range plans that mutually benefit both parties (Hauser et al, 2003:1). In 2004, Belzowski, Flynn, Edwards, Ban and Martin, (18) agreed with the need for trust as a basis for collaboration.

Schonsleben and Hieber (2001:9) stated that supply chain networks required a new approach in performance measurement in order to achieve the network objective(s). While traditional performance 
management focused on short-term optimisation and financial focus, the approach must be networkorientated, partnership-orientated, balance-orientated and business-process-orientated (Schonsleben \& Hieber, 2001:12).

As in the case of the similar characteristics of entrepreneurial networks, Schonsleben and Hieber (2001:10) identified the key characteristics in the configuration of the supply chain as depth of network (multi-tier network), breadth of network (multi-channel network) and time horizon of business relationships (comparable with the dynamic nature of entrepreneurial networks over time).

Walker (2005:39) identified the following questions that should be raised when establishing supply chain relationships or networks:

- $\quad$ have you mapped your supply chain networks?

- $\quad$ is your business focused on the end customer?

- $\quad$ do you understand the boundaries of your core competencies? and

- $\quad$ have you aligned your supply chain network with your business strategy?

(Walker, 2005:39).

In order to research empirically the impact of the principles of entrepreneurial networking on supply chain relationships, it is suggested that an exploratory study be conducted in the automotive component industry in South Africa at a later stage.

\section{An Overview of the Automotive Component Industry in South Africa}

This section of the article deals with a brief overview of the automotive component industry in South Africa.

\section{Introduction}

The automotive industry is often described as one of the most global of all industries. Its products are spread around the world and it is dominated by a small number of companies with global recognition (Humphrey \& Memodovic, 2003:2). As indicated in Naude (2009:50), South Africa's automotive industry is an important contributor to the country's GDP and employment opportunities. In terms of its international contribution, globally, the industry ranked $20^{\text {th }}$ in 2006 in terms of vehicle production. South Africa was responsible for approximately $85 \%$ of Africa's vehicle output and produced $0.85 \%$ of the world's vehicles in 2006 (NAAMSA Annual Report 2007:10).

Morris, Donnelly and Donnelly (2004:129) acknowledge that the automotive industry has experienced great structural and other changes in the last 20 years. The influences of globalisation, the implementation of lean production and the development of modularisation have had great influences on the relationships between original equipment manufacturers and their suppliers, particularly those in the first tier, known as automotive component manufacturers.

South Africa has a number of original equipment manufacturers, namely, BMW, Ford, Volkswagen, Daimler-Chrysler and Toyota who all have assembly plants in various parts of the country. Vehicles are assembled for both the local and international market (Tera, 2003:1). In addition, South Africa has a vibrant automotive component manufacturing industry which supplies these original equipment manufacturers (Trade and Investment South Africa (TISA), 2003:27).

There are 278 first tier suppliers (a small group of suppliers who supply directly to original equipment manufacturers) and more than 150 second tier and third tier suppliers that are spread throughout the country. Just under half of these suppliers are located in Gauteng, a third in the Eastern Cape, a quarter in KwaZulu-Natal and a few companies in the Western Cape (Mbiko, 2007:3).

\section{Turnover}

As indicated in South Africa Automotive Yearbook, 2008, Section 2.1, the National Association of Automotive Component and Allied Manufacturers, (NAACAM) was launched 26 years ago to represent the interests of automotive component manufacturers. This body is both nationally and internationally 
recognised as the voice of the South African automotive component industry. NAACAM consists of some 190 national member companies with 260 regional companies. In addition there are some foreign and smaller local companies which are either not members of any association or are affiliated to plastics, stainless steel, aluminium and similar bodies.

\section{The Case for the Implementation of Entrepreneurial Networking in Supply Chain Relationships in the Automotive Industry}

It could be argued that the underlying principles of entrepreneurial networking could apply to all supply chain relationships in the business environment as all the supply chain relationships occur within an entrepreneurial setting. The authors do not contest this argument. The reason for having chosen the automotive component industry in South Africa in particular was that this industry is particularly vulnerable to global market volatility, price competition and quality issues within relatively hostile markets. Original equipment manufacturers wield most of the power in relationships. This is evident from a recent study conducted by Naude (2009:190) where suppliers to original equipment manufacturers indicated that as far as they were concerned, original equipment manufacturers "dictate" to these suppliers about what is expected from them.

One of the potential benefits of applying the principles of entrepreneurial networking in supply chain relationships in the automotive component industry is that of gaining a competitive advantage, the result of which could increase the overall profitability and success of the parties in the supply chain and consequently help to establish more stability and profitability in this sector.

The similarities between entrepreneurial networking and supply chain relationships are based on the approach that these characteristics are applicable to both entrepreneurial networking and supply chain management. The extent to which these characteristics are applied in the real world would differ from business to business. The potential value of implementing all these characteristics could be very beneficial to most businesses as they are all linked to the pursuit of sustainability and long term profitability.

From a supply chain point of view in the automotive component industry in South Africa in particular, it is important to base the establishment of relationships on the entrepreneurial networking principles.

\section{Conclusion}

This article reasoned that the principles underlying entrepreneurial networking could be applied to supply chain relationships in general and the automotive component manufacturing industry in South Africa in particular. The reasoning was mainly based on the sustainability and profitability potential of entrepreneurial networking as pointed out in the literature review and the similarities that existed between entrepreneurial networking and supply chain management relationships as the latter also operated within an entrepreneurial setting. In addition to this argument the unique challenges facing an industry currently under threat in the global market, such as the automotive component manufacturing industry, further strengthened the case for the implementation of entrepreneurial networking.

\section{Recommendations}

Based on the arguments presented and the guidelines given, it is recommended that automotive component manufacturers should consider implementing the principles of entrepreneurial networking in their businesses, albeit on an experimental basis, in order to adapt it to their unique requirements so to improve their sustainability and growth.

\section{Limitations}

A major limitation of this article was that no empirical study was conducted to test the implementation of entrepreneurial networking within the automotive component manufacturing industry.

\section{Suggestions for further research}

It is suggested that further research be conducted to include primary research to empirically test the implementation of entrepreneurial networking within the automotive component manufacturing industry. 


\section{REFERENCES}

Aldrich, H. (1999). Organisations evolving. London: Sage Publications.

Baum, J.A.C., Calabrese, T. \& Silverman, B.S. (2000). Don't go it alone: alliances network compositions and start-ups performance in Canadian biotechnology. Strategic Management Journal, Vol.21, No.3, pp.267-294.

Belzowski, B.M., Flynn, M.S., Edwards, M., Ban, L. \& Martin, G. (2004). Supply chain management: new competitive realities in the automotive value chain. IBM Institute for Business Value in association with OSAT, University of Michigan Transportation Research Institute. Somers, NY: IBM Corporation.

Beth, S., Burt, D.N., Copacino, W., Gopal, C., Lee, H.L., Lynch, R.P. \& Morris, S. (2006). Supply chain challenges: building relationships. Harvard Business Review on Supply Chain Management. Boston: Harvard Business School Press.

Burt, R.S. (1998). The gender of social capital. Rationality and Society, Vol.10, No.1, pp.5-46.

Burt, D.N., Petcavage, S. \& Pinkerton, R. (2010). Supply management. $8^{\text {th }}$ edition. Boston: Irwin McGrawHill.

Candler, R, (1998). The Influence of Eastern and Western business cultures in the automotive industry. University of Bristol. Online] Available from: http://www.dig.bris.ac.uk/teaching/o_a_hf/rcand/rcand.htm. [Accessed 21 April 2006].

Christopher, M. (2005). Logistics and supply chain management: creating value-adding networks. $3^{\text {rd }}$ edition. Harlow: FT Prentice Hall.

Davidsson, P. \& Honig, B. (2003). The role of social and human capital among nascent entrepreneurs. Journal of Business Venturing, Vol. 18, No.3, pp.301-331.

Dean, J., Holmes, S. \& Smith, S. (1997). Understanding business networks evidence from the manufacturing and service sectors in Australia. Journal of Small Business Management, Vol. 35, No.1, pp.78-84

Edmonds, J.J. (2005). The potential impact of entrepreneurial networks on the success of SME's: an exploratory study. Unpublished B. Com Honours Dissertation. University of KwaZulu-Natal, Pietermaritzburg Campus.

Goudis, A. \& Skuras, D. (2000). "Conceptual paper: business networks." ASPIRE, Department of Economics, University of Patras, pp.1-35.

Handfield, R.B., Monczka, R.M., Giunipero, L.C. \& Patterson, J.L. 2009. Sourcing and supply chain management. $4^{\text {th }}$ edition. Mason, $\mathrm{OH}$ : South-Western, Cengage Learning.

Hauser, T., Davis, F. \& Graham, J. (2003). Supplier relationship management models, considerations and implications for DOD. Washington, D.C.: Industrial College of the Armed Forces, National Defence University.

Heizer, J. \& Render B. (2008). Principles of operations management. $7^{\text {th }}$ edition. Upper Saddle River, NJ: Prentice Hall.

Hoang, H. \& Antocic, B. (2003). Network-based research in entrepreneurship: a critical review. Journal of Business Venturing, Vol.18, No.2, pp. 165-187. 
Hugo, W.M.J., Badenhorst-Weiss, J.A. \& van Biljon E.H.B. (2004). Supply chain management: logistics in perspective. Pretoria: Van Schaik.

Hugo, W.M.J., Badenhorst-Weiss, J.A. \& Van Biljon, E.H.B. (Eds) (2006). Purchasing and supply chain management. $5^{\text {th }}$ edition. Pretoria: Van Schaik Publishers.

Human, S.E. \& Provan, K.G. 1997. An emergent theory of structure and outcomes in small firm strategic networks. Academy of Learning Journal, Vol. 40, No. 2, pp.368-403.

Humphrey, J. \& Memedovic, O. (2003). The Global Automotive Industry Value Chain: What Prospects for Upgrading by Developing Countries. Vienna: United Nations Industrial Development Organisation (UNIDO).

lyer, A.V., Seshadri, S. \& Vasher, R (2009) Toyota supply chain management. A strategic approach to the principles of Toyota's renowned system. New York: McGraw-Hill.

Johnsson, P. (2005) Logistics and Supply Chain Management. London: McGraw-Hill.

Kirzner, I.M. 1973. Competition and entrepreneurship. Chicago: The University of Chicago Press.

Kotler, P., Armstrong, G., Saunders, J. \& Wong, V. (2002). Principles of Marketing. Third European Edition. Harlow, England: FT Prentice Hall.

Liker, JK \& Choi, TY. 2006. Building deep supplier relationships. Harvard Business Review on Supply Chain Management. Boston: Harvard Business School Press. Reprint R04120, pp.23-47.

Lysons, K. \& Gillingham, M. (2003). Purchasing and supply chain management. $6^{\text {th }}$ edition. Harlow: Prentice Hall Financial Times.

Mbiko, E. (2007). Definitive Reference, statistics and Data on the South African Motor Industry. Section 7: Logistics, Import and Export. $11^{\text {th }}$ edition. KwaZulu Natal: Balgair Publications.

McEvily, B. \& Zaheer, A. (1999). Bridging ties: a source of firm heterogeneity in competitive capabilities. Strategic Management Journal, Vol. 20, No.12, pp.1133-1156.

Mitchell,R.K., Busenitz, L.W.,Bird, B., Gaglio, C., McMullen, J.S., Morse, E.A. \& Smith, J.B. (2007). The central question in entrepreneurial cognition research 2007. Entrepreneurship Theory and Practice, Vol. 31, pp.1-27.

Monczka, R.M., Handfield, R.B., Giunipero, L.C \& Waters, D (2010). Purchasing \& supply chain management. Australia: South-Western Cengage Learning.

Morris, D, Donnelly, T \& Donnelly, T (2004). Supplier Parks in the Automotive Industry. Supply Chain Management: An International Journal. Vol. 9. No. 2. 2004. pp 129-133. Emerald Group Publishing Limited

NAAMSA Annual Report. 2007.

Naude, M.J.A. (2009). Supply chain management problems experienced by South African automotive component manufacturers. Unpublished Doctorate Thesis: Unisa.

Naude, S.A. \& O'Neill, R.C. (2010) The effects of the global economic crisis on the automotive component industry in KwaZulu-Natal. The 3rd International UJ Faculty of Management Conference, 1214 May 2010. 
Nobria, N. \& Eccles, R.G. (1992). Networks and Organisations. New York: Harvard Business School Press.

O'Neill, C. (2009). Challenges to research on entrepreneurial networking in SMEs. International Journal of Economics and Business Research, Vol.1, No.4, pp.467-478.

O'Neill, C., Soni, S., Coldwell, D. \& Edmonds, J. (2007). Towards a testable model of the impact of specific entrepreneurial networks on the success of businesses in the Pietermaritzburg region. Conference Paper presented at the 2007 Southern African Institute of Management Scientists Conference, Sandton.

Premaratne, S.P. (2002). Entrepreneurial networks and small business development: the case of small enterprises in Sri Lanka. Unpublished PhD Thesis.

Quesada, G., Syamil, A. \& Doll, W.J. (2006). OEM new product development practices: the case of the automotive industry. The Journal of Supply Chain Management Vol. 42, No.3, summer: 40-41.

Schonsleben, P. and Hieber, R. (2001). Collaborative performance measurement for supply chain management. Conference paper presented at Supply Chain World Europe Conference, 1-3 October 2001, Berlin.

Simchi-Levi, D., Kaminsky, P. and Simchi-Levi, E. (2003) Designing and managing the supply chain: Concepts, Strategies and Case Studies. $2^{\text {nd }}$ edition. Boston: Irwin McGraw-Hill.

Singh, R.P., Hills, G.E. and Lumpkin, G.T. (1999). New venture ideas and entrepreneurial opportunities: understanding the process of opportunity recognition. Paper presented at the $13^{\text {th }}$ Annual Conference of the United States Association for Small Business and Entrepreneurship, pp.1-10.

Slone, R.E., Mentzer, J.T. \& Dittmann, J.P. (2007). Are you the weakest link in your company's supply chain? Harvard Business Review. September 2007, pp. 116-127.

Stevenson, W.J. (2005) Operations Management. $8^{\text {th }}$ edition. International Edition. Boston: McGraw-Hill.

Taylor, D.W., Jones, O. \& Boles, K. (2004). Building social capital through action learning and insight into the entrepreneur. Education and Training, Vol. 46, No.5, pp.226-235.

Tera, M. (2003). Government programmes support the creation of new jobs. 31 July. [Online] Available from: http: //www.unitedworldsa.com/reports/southafrica/ industry.asp. [Accessed 23 February 2004].

Thompson, A. A., Gamble, J.E. \& Strickland, A.J. (2006).Strategy winning in the marketplace: core concepts, analytical tools and cases. $2^{\text {nd }}$ edition. New York: McGraw Hill//rwin.

Trade and Investment South Africa (TISA). Current developments in the Automotive Industry. (2003). Seventh Report. Pretoria: The Department of Trade and Industry.

Tsai, W. \& Ghoshal, S. (1998). Social capital and value creation. Academy of Learning Journal. Vol.58, No.4, pp.581-628.

Walker, W.T. (2005). Supply Chain architecture. Boca Raten: CRC Press.

Williams, C. 2004. National Association of Automotive Component and Allied Manufacturers. [Online] Available from: http://www.naacam.co.za/sami.htm. [Accessed 23 February 2004].

Wisner, JD, Keong, G \& Tan, KC. 2005. Principles of supply chain management: a balanced approach. International student edition. Australia: Thomson South-Western. 